\title{
Fintech Innovations: The Impact of Mobile Banking Apps on Bank Performance in Vietnam
}

\author{
Tam T. Le ${ }^{1}$, Ha N. Mai ${ }^{2}$, Duong T. Phan ${ }^{3}$, Mai N.T. Nguyen ${ }^{4}$, Hoang D. Le \\ ${ }^{1}$ School of Banking and Finance, National Economics University, Vietnam \\ ${ }^{2,3,4}$ School of Advanced Educational Programs, National Economics University, Vietnam \\ ${ }^{5}$ Faculty of Economic Mathematics, National Economics University, Vietnam
}

Corresponding Author: Tam T. Le

\section{ABSTRACT}

This paper is aimed at analyzing the impact of FinTech innovations on bank performance across mobile banking applications in Vietnam. Using the longitudinal panel data from 20102019 (with 220 observations) of 22 local commercial banks in Vietnam. Multivariate panel regression is chosen to experimentally test the research hypotheses. This research paper is one of the first quantitatively investigating the effects of fintech innovation (mobile banking apps) on bank performance in Vietnam. In addition, studies on financial indicators are shown quite comprehensively in the period 2010-2019. Our empirical study has shown the following results: (i) FinTech innovations' positive impact on bank performance in Vietnam; (ii) Banks' adoption of mobile banking technologies positively impacted banks' fee-based income, consumer loans and money market deposits; (iii) The effect of mobile technologies on financial performance was much stronger for small banks than large banks; (iv) As for the balance sheet liabilities aspect, the money market fund of small banks is positively affected by the mobile banking application; (v) In terms of balance sheet assets, consumer loans by small banks are positively affected by the mobile banking application while large banks are not; (vi) GDP per capita has a positive effect on the ROE of both small and large banks; (vii) Mobile phone penetration rates positively affected bank ROA and ROE and its effect was larger on small banks. From the findings, key recommendations to Vietnamese commercial banks to improve bank performance in the context of an increasingly technological development are to: (1) Increase
\end{abstract}

investment in mobile banking apps and the entire mobile banking technology; (2) Increase investment in financial technology, focus more on mobile banking users and the entire mobile banking services; (3) Take advantage of the technical support and consultancy of international organizations and bilateral cooperation with other countries' authorities in management of Fintech businesses; (4) Learn from commercial banks in other countries to draw experiences, thereby develop in own context. (5) Training human resources for the finance and banking industry to not only have professional knowledge and ability to analyze data, but also have to be proficient in operating digital technology.

Keywords: Fintech Innovations, mobile banking apps, bank performance, Vietnam, theories of Technological Innovation

\section{INTRODUCTION}

FinTech can be understood as the application of technological innovations to provide financial services (Gomber, Koch, \& Siering, 2017). These services may be formed based on new innovative ideas, or maybe outdated but provided in a new way with the purpose to simplify transaction procedures and help to improve access to financial services of customers (Gomber et al., 2017; Milian, Spinola, \& Carvalho, 2019; Phan, Nguyen, \& Bui, 2019). Therefore, FinTech plays a significant role in the development of the banking industry. The trend of technology application in the financial sector (FinTech) taking place very 
strongly has brought many opportunities as well as challenges for business operations in general, payment service development activities based on digital banking technology in particular of commercial banks. New forms of financial transactions such as FinTech have emerged to compete with traditional banks (Lee, 2015).

Fintech innovation, in particular, Mobile banking apps recently developed strongly in the digital era of the industrial revolution 4.0, especially in the field of Finance- Banking. Around the world, there are quite a number of theoretical and applied studies on the impact of mobile banking apps on bank performance. However, empirical studies on how Mbanking apps affect the overall performance of the banking sector are still few, particularly in Vietnam, where there is no empirical study. Furthermore, in the 4th industrial revolution, it is critical to investigate the effect of mobile banking applications on banking indicators.

Multivariate panel regression is chosen to experimentally test the research hypotheses on whether there is any correlation between different research variables about the FinTech innovations and bank performance. The STATA 14 and Excel tool is used to run multivariate panel regression models. To estimate parameters in regression equations and independently evaluated coefficients, the usual least squares (OLS) method is used.

\section{RESEARCH MODEL AND HYPOTHESIS}

Our research model and hypotheses are conducted based on the ordinary least squares (OLS) model and Theories of Technological Innovation (Schumpeter, 1934)

H0: Adoption of mobile technologies has no impact on all financial indicators across all banks

H1: Adoption will have a bigger impact on small banks than on large banks in terms of fee income
$\mathrm{H} 2$ : Adoption will have a bigger impact on small banks than on large banks in terms of operating cost

H3: Adoption will have a bigger impact on small banks's customer loans than on large banks

H4: Adoption will have a bigger impact on small banks's ROA than on large banks

H5: Adoption will have a bigger impact on small banks's ROE than on large banks

\section{RESEARCH METHODOLOGY 1. Data collection and sample}

This research will use a variety of data samples to analyze the effects of fintech reform in banking performance of 22 local commercial banks from 2010-2019 in Vietnam as after:

- Balance sheet and income statement from 2010 to 2019 are retrieved by Vietstock Finance

- Annual reports from 2010 to 2019 are retrieved from each bank's website

- Age of mobile banking apps from release year to 2019 is retrieved by AppAnnie

- Notifications and news from each bank website to identify FinTech operations, strategy and performance

- News and regulations from the central bank website to identify legal regulations governing FinTech's operations as well as commercial banks and the current state of payments.

\section{Research Variables}

The research results of the independent variables based on FinTech innovation include age of mobile banking applications, GDP per capita, and mobile penetration rates. The result of the dependent variable is the performance of the bank. This study looks at 17 separate financial metrics, such as income stream, expenditure structure, balance sheet composition and profitability, such as ROA, ROE shown in Table 1. 
Tam T. Le et.al. Fintech innovations: the impact of mobile banking apps on bank performance in Vietnam.

Table 1: Summary of Research Variables

\begin{tabular}{|c|c|c|c|}
\hline $\begin{array}{l}\text { Name } \\
\text { Variable }\end{array}$ & Description & Hypothesis & References \\
\hline \multicolumn{4}{|c|}{ Independent Variables for FinTech Innovations } \\
\hline MBA_AGE & $\begin{array}{l}\text { Mobile banking application age is provided } \\
\text { by banks from the first release year to } 2019\end{array}$ & & \\
\hline GDP_PC & $\begin{array}{l}\text { GDP per capita of Vietnam for the period } \\
2010-2019\end{array}$ & + & $\begin{array}{l}\text { Hai T. Phan, Tien N. Hoang, Linh V. Dinh, Dat N. } \\
\text { Hoang (2020); Shen, Liao \& Weyman-Jones (2009), } \\
\text { Haron (2012) }\end{array}$ \\
\hline MPP_RATE & $\begin{array}{l}\text { Vietnam's mobile phone penetration rate } \\
\text { 2010-2019 }\end{array}$ & + & $\begin{array}{l}\text { Abbasi \& Weigand(2017), } \\
\text { Scott, Reenen \& Zachariadis (2017) }\end{array}$ \\
\hline \multicolumn{4}{|c|}{ Dependent Variables for Bank Performance } \\
\hline \multicolumn{4}{|c|}{ a. Income Statement } \\
\hline INIC_ASS & Total Interest Income / Total Assets & + & DeYoung (2007), Khanh N.Nguyen(2019) \\
\hline INEX_ASS & Total Interest Expenses / Total Assets & + & $\begin{array}{l}\text { Khanh N.Nguyen(2019), } \\
\text { DeYoung (2007) }\end{array}$ \\
\hline FEIN_ASS & $\begin{array}{l}\text { Total Noninterest Income } \\
\text { /Total Assets }\end{array}$ & + & DeYoung \& Rice (2003) \\
\hline SALA ASS & Total Salaries / Total Assets & + & Kiyono H.(2019) \\
\hline SGA_ASS & $\begin{array}{l}\text { Total Selling General \& Admin Exp / Total } \\
\text { Assets }\end{array}$ & + & Kiyono H.(2019) \\
\hline \multicolumn{4}{|l|}{ b. B/S (Assets) } \\
\hline CASH_ASS & Total Cash / Total Assets & + & Finastra, (2018) \\
\hline SEC_ASS & Total Securities / Total Assets & + & Kiyono H.(2019) \\
\hline LOAN ASS & Total Loans / Total Assets & + & Kiyono H.(2019) \\
\hline COMLO_LOAN & Total Commercial Loans / Total Loans & - & DeYoung, (2004) \\
\hline CONSLO_LOAN & Total Consumer Loans / Total Loans & + & Kiyono H.(2019) \\
\hline NPL_LOAN & Non-performing Loans / Total Loans & + & Atoi, Ngozi V. (2018) \\
\hline Adj_ROA & $\begin{array}{l}\text { The adjusted return on assets indicates the } \\
\text { ratio of average net returns to average assets }\end{array}$ & + & $\begin{array}{l}\text { Tunay and Akhisar (2015), Japparova and Rupeika- } \\
\text { Apoga (2017) }\end{array}$ \\
\hline \multicolumn{4}{|c|}{ c. B/S (Liabilities and Equity) } \\
\hline DEPO_ASS & Total Deposits / Total Assets & - & Kiyono H.(2019) \\
\hline DD_DEP & Total Demand Deposits / Total Deposits & - & Kiyono H.(2019) \\
\hline MM_DEP & $\begin{array}{l}\text { Money Market and Savings Account } \\
\text { Deposits / Total Deposits }\end{array}$ & + & Kiyono H.(2019) \\
\hline Adj_ROE & $\begin{array}{l}\text { Return on equity is adjusted for the average } \\
\text { net return per shareholder } \\
\text { fair }\end{array}$ & - & Zetin(2017),Campanella and Dezi (2016) \\
\hline \multicolumn{4}{|c|}{ Control Size - Grouping Criteria } \\
\hline GROUP_SZ & $\begin{array}{l}\text { Size of the full sample of } 22 \text { banks. Take the } \\
\text { median asset size; Large Banks > VND } 150 \\
\text { trillion < Small Banks }\end{array}$ & & \\
\hline
\end{tabular}

Table 2 : Descriptive Analysis of Research Variables in the equation model

\begin{tabular}{|c|c|c|c|c|c|}
\hline Variables & Sample size & Mean & Std.Dev & Max & Min \\
\hline \multicolumn{6}{|c|}{ Independent Variables For FinTech Innovations } \\
\hline MBA_AGE & 220 & 2.27 & 2.217 & 8 & 0 \\
\hline GDP_PC & 220 & 2384.6 & 233.143 & 2715 & 2085 \\
\hline MPP_RATE & 220 & 0.36 & 0.06 & 0.45 & 0.26 \\
\hline \multicolumn{6}{|c|}{ Dependent Variables For Bank Performance } \\
\hline \multicolumn{6}{|l|}{$B / S($ Assets ) } \\
\hline INIC_ASS & 220 & 0.067 & 0.014 & 0.132 & 0.042 \\
\hline INEX_ASS & 220 & 0.042 & 0.010 & 0.072 & 0.003 \\
\hline FEIN_ASS & 220 & 0.002 & 0.002 & 0.014 & -0.0017 \\
\hline CASH_ASS & 220 & 0.008 & 0.004 & 0.024 & 0.007 \\
\hline SEC_ASS & 220 & 0.178 & 0.073 & 0.468 & 0.016 \\
\hline LOAN_ASS & 220 & 0.616 & 0.102 & 0.854 & 0.269 \\
\hline COMLO_LOAN & 220 & 1.854 & 0.648 & 0.483 & 0.254 \\
\hline CONSLO_LOAN & 220 & 0.987 & 0.003 & 0.992 & 0.976 \\
\hline Adj_ROA & 220 & 0.787 & 0.702 & 2.95 & 0.01 \\
\hline \multicolumn{6}{|l|}{$B / S(L$ and $E)$} \\
\hline DEPO_ASS & 220 & 0.699 & 0.108 & 0.893 & 0.461 \\
\hline Adj_ROE & 220 & 9.96 & 7.76 & 27.73 & 0.08 \\
\hline \multicolumn{6}{|c|}{ Control Variables (Bank size) } \\
\hline SIZE_VND & 220 & $274.892 .901,5$ & $475.504 .597,6$ & 1.489 .957 .293 & 31.574 .084 \\
\hline
\end{tabular}

\section{Analytical Methods}

This study is performed by multivariate panel regression analysis from tabular data on banking and finance in the period 2010-2019. In which, many financial indicators are regression based on each bank's mobile banking technology application status. The model of equations 
below represents the linear relationship between mobile banking technology and bank performance:

$$
\text { Yit }=\mathrm{c}+\alpha^{*} \text { MBA_AGEit }+ \text { eit }
$$

\section{RESULTS AND DISCUSSION 1. Regression Analysis}

Years of mobile banking are counted from the first year of a mobile application released by sample banks to 2019. The regression model console is run separately for a full sample of 22 banks domestic trade in Vietnam (220 observations) in the period 2010-2019. For the study independent variables, a mobile banking application was used (MBA_AGE). In addition, the additional independent research variables of GDP Per Capita and Mobile Phone penetration rate is included in the panel regression to measure the influence of macroeconomic and market conditions. Coefficients are indicated in the table with the probability value ( $\mathrm{p}$-value) is as follows: * $\mathrm{p}<0.1$; ** $\mathrm{p}<0.05$; *** $\mathrm{p}<0.01$. This study specifically looks at coefficients with p-values less than 0.01 and 0.05 with $R$ adjusted 2 out of $50 \%$ are statistically significant.

Table 3 : Effect of mobile technology on financial performance of all banks

Estimation method: OLS

Full Sample (2010-2019: 220 observations)

\begin{tabular}{|l|l|l|}
\hline Independent Variables & MBA_AGE & Adj R-sq
\end{tabular}

Dependent Variables

Income statement

\begin{tabular}{|l|l|l|}
\hline INIC_ASS & $0.253^{* * *}$ & 0.742 \\
\hline
\end{tabular}

\begin{tabular}{|l|l|l}
\hline INEX_ASS & $0.253 * * *$ & 0.742 \\
\hline & $0.091 * *$ & 0.698 \\
\hline
\end{tabular}

\begin{tabular}{|c|c|}
\hline FEIN_ASS & $0.067 * *$ \\
\hline
\end{tabular}

\begin{tabular}{|l|l|l}
\hline SALA_ASS & $0.038^{* *}$ & 0.617 \\
\hline SGA_ASS & $0.016^{* * *}$ & 0.843
\end{tabular}

Balance sheet (Assets side)

\begin{tabular}{|l|l|l|}
\hline CASH_ASS & 2.736 & 0.389 \\
\hline SEC_ASS & 7.850 & 0.411
\end{tabular}

\begin{tabular}{|l|l|l}
\hline LOAN_ASS & 0.485 & 0.236 \\
\hline COMLO & -0.173 & 0.089
\end{tabular}

\begin{tabular}{l|l|l}
\hline COMLO_LOAN & 0.485 & 0.236 \\
\hline & -0.173 & 0.089
\end{tabular}

\begin{tabular}{|c|c|c|}
\hline CONSLO_LOAN & $1.762 * *$ & 0.85 \\
\hline NPL_LOAN & $0.233 * *$ & 0.3 \\
\hline
\end{tabular}

\begin{tabular}{|l|l|l|}
\hline Adj_ROA & $0.956^{* *}$ & 0.311 \\
\hline Balance & 0.563 \\
\hline
\end{tabular}

Balance sheet ( Liabilities and Equity side)

\begin{tabular}{|l|l|l|}
\hline DEPO_ASS & -0.037 & 0.0441 \\
\hline DD_DEP & $-0.056^{* * *}$ & 0.812 \\
\hline MM_DEP & $0.699^{* *}$ & 0.809 \\
\hline TD_DEP & $-1.379^{* *}$ & 0.778 \\
\hline Adj_ROE & $-0.535^{* * *}$ & 0.623 \\
\hline Fixed Effects: Bank Name and Year \\
\hline *p<0.1; **p<0.05; ***p<0.01
\end{tabular}

Source: Authors' compilation result (2021)
The full sample's fee income (FEIN_ASS) was positively affected by the banking app at $0.067 * *$ with the adjusted $R 2$ at $72.5 \%$. The fee income includes securities trading fees, account service fees, foreign exchange fees, loan and credit usage fees.

As of 2019, all the local commercial banks that we have selected are in Vietnam have adopted the mobile banking app. They are divided into two groups by the median asset size; small banks for less than VND 150 trillion and large banks for more than VND 150 trillion.

On the asset side of the balance sheets, consumer loans are most affected by the mobile banking apps (CONSLO_LOAN, $1.762 * *$ ) with the adjusted R2 higher at $85 \%$. Mobile banking apps are getting more and more gadgets. Therefore, it facilitates consumer loans and investments

Table 4 : Effect of mobile technology on small banks

\begin{tabular}{|c|c|c|}
\hline \multicolumn{3}{|c|}{ Estimation method: OLS } \\
\hline \multicolumn{3}{|c|}{ Small Banks (2010-2019: 110 observations) } \\
\hline Independent Variables & MBA_AGE & Adj R-sq \\
\hline \multicolumn{3}{|l|}{ Dependent Variables } \\
\hline \multicolumn{3}{|l|}{ Income statement } \\
\hline INIC_ASS & -0.017 & 0.517 \\
\hline INEX_ASS & -0.024 & 0.748 \\
\hline FEIN_ASS & $0.225 * * *$ & 0.612 \\
\hline SALA_ASS & $-0.596 * *$ & 0.753 \\
\hline SGA_ASS & $-0.071 * *$ & 0.852 \\
\hline \multicolumn{3}{|c|}{ Balance sheet (Assets side) } \\
\hline CASH_ASS & 5.215 & 0.512 \\
\hline SEC_ASS & 7.320 & 0.314 \\
\hline LOAN_ASS & 2.96 & 0.277 \\
\hline COMLO_LOAN & -2.193 & 0.635 \\
\hline CONSLO_LOAN & $4.288 * * *$ & 0.718 \\
\hline NPL_LOAN & -0.136 & 0.215 \\
\hline Adj_ROA & $0.192 * * *$ & 0.672 \\
\hline \multicolumn{3}{|c|}{ Balance sheet ( Liabilities and Equity side) } \\
\hline DEPO_ASS & -0.981 & 0.403 \\
\hline DD_DEP & $-0.852 * * *$ & 0.647 \\
\hline MM_DEP & $5.816 * * *$ & 0.829 \\
\hline TD_DEP & $-2.497 * * *$ & -0.572 \\
\hline Adj_ROE & $1.583 *$ & 0.678 \\
\hline \multicolumn{3}{|c|}{ Fixed Effects: Bank Name and Year } \\
\hline \multicolumn{3}{|c|}{$* \mathrm{p}<0.1 ; * * \mathrm{p}<0.05 ; * * * \mathrm{p}<0.01$} \\
\hline
\end{tabular}

Key finding is that mobile technology did not affect interest income and interest expense across small and large banks. Instead small banks' fee income was positively affected by the mobile technology at $0.225^{* * *}$ with the adjusted $R 2$ at $61.2 \%$, supporting the first hypothesis. 
Bank salary and SG\&A expenses of small banks were negatively affected by the mobile banking app, supporting the second hypothesis on the operating cost reduction.

Among the variables, the most significant finding came from the consumer loans which were positively affected by the mobile banking app, and its effect was much larger on small banks, supporting the second hypothesis. (CONSLO_LOAN, 4.288***; $71.8 \%$ adjusted $R 2$ ). This is the highest coefficient whereby a yearly increase in the mobile banking app adoption will grow small banks' consumer loans by $4.288 \%$, supporting the third hypothesis.

Overall cash assets and securities assets were positively affected by the mobile banking app. Loan assets were positively affected by mobile banking apps. The adjusted ROA of large banks was positively affected by the banking app at $0.096^{* *}$ lower than the small banks' coefficients at $0.192 * * *$, supporting the fourth hypothesis.

Deposits assets were negatively affected by the banking app at $-2.183^{* *}$ with the adjusted $R 2$ at $86.7 \%$ as well. The adjusted ROE was negatively affected by the mobile banking app at $0.780 * *$ with the adjusted $R 2$ at $66 \%$. These results demonstrate that mobile technologies did not positively affect financial performance of large banks, supporting the fifth hypothesis for the larger technological effects on small banks.

Table 5 : Effect of mobile technology on large banks

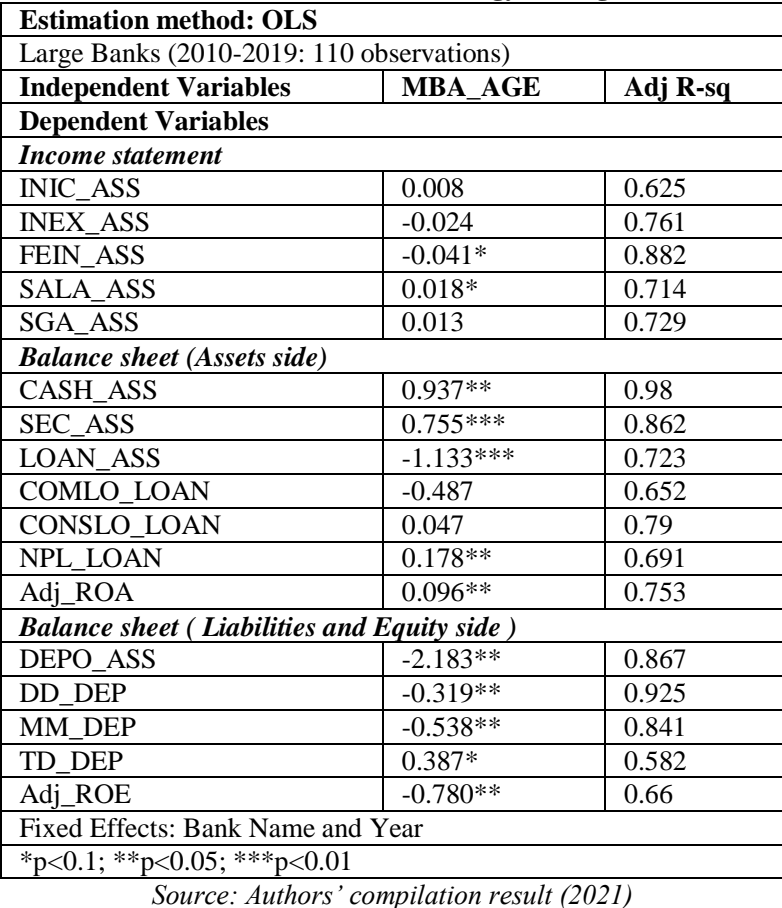

Large banks' income statements were largely unaffected, supporting the hypothesis of the mobile technology effect on small banks.

\begin{tabular}{|c|c|c|c|c|}
\hline \multicolumn{5}{|l|}{ Estimation method: OLS } \\
\hline \multicolumn{5}{|c|}{ Full sample (2010-2019: 220 observations) } \\
\hline Independent Variables & Adj R-sq (MPP_RATE) & MPP RATE & GDP_PC & Adj R-sq (GDP) \\
\hline \multicolumn{5}{|l|}{ Dependent Variables } \\
\hline Adj_ROA & 0.714 & $0.0045^{* * *}$ & $-0.000 * *$ & 0.541 \\
\hline Adj_ROE & 0.593 & $-0.1611 * *$ & $0.00013^{* * *}$ & 0.647 \\
\hline \multicolumn{5}{|c|}{ Fixed Effects: Bank Name and Year } \\
\hline${ }^{*} \mathrm{p}<0.1 ; * * \mathrm{p}<0.05 ; * * * \mathrm{p}<$ & & & & \\
\hline
\end{tabular}

The adjusted ROE of all banks that adopted mobile banking apps was positively affected by GDP per capita at $0.00013^{* *}$ with the adjusted $R 2$ at $64.7 \%$. Meanwhile, the adjusted ROA of all banks using the mobile banking app is negatively affected by GDP per capita at $-0.00004 * *$ with the adjusted $R 2$ of $54.1 \%$.
The adjusted ROE of all banks that adopted mobile banking apps was negatively affected by mobile phone penetration rates at $-0.1611^{* *}$ with the adjusted $R 2$ at $59.3 \%$. Meanwhile, the adjusted ROA of all banks using the mobile banking app is positively affected at $0.0045^{* * *}$ with the adjusted $R 2$ of $71.4 \%$. 
Tam T. Le et.al. Fintech innovations: the impact of mobile banking apps on bank performance in Vietnam.

\begin{tabular}{|c|c|c|c|c|}
\hline \multicolumn{5}{|l|}{ Estimation method: OLS } \\
\hline \multicolumn{5}{|c|}{ Small banks (2010-2019: 110 observations) } \\
\hline Independent Variables & Adj R-sq (MPP_RATE) & MPP_RATE & GDP_PC & Adj R-sq (GDP) \\
\hline \multicolumn{5}{|l|}{ Dependent Variables } \\
\hline Adj_ROA & 0.649 & $0.073^{*}$ & -0.0006 & 0.589 \\
\hline Adj_ROE & 0.752 & $0.106^{* * *}$ & $0.00018^{* * *}$ & 0.632 \\
\hline \multicolumn{5}{|c|}{ Fixed Effects: Bank Name and Year } \\
\hline$* \mathrm{p}<0.1 ; * * \mathrm{p}<0.05 ; * * * \mathrm{p}<$ & .01 & & & \\
\hline
\end{tabular}

There is a relationship observed between GDP per capita and adjusted ROE at $0.00018^{* *}$ with the adjusted $R 2$ at $63.2 \%$.

The adjusted ROE of small banks was positively affected by mobile phone penetration rates at $0.106^{* *}$ with the adjusted $R 2$ at $75.2 \%$. Meanwhile, the adjusted ROA was also positively affected at $0.073^{*}$ with the adjusted $R 2$ of $64.9 \%$

Table 8: Effects of GDP per capita, mobile phone penetration rates on ROA and ROE (Large banks)
\begin{tabular}{|l|l|l|l|l|}
\hline Estimation method: OLS \\
\hline Large banks (2010-2019: 110 observations) \\
\hline Independent Variables & Adj R-sq (MPP_RATE) & MPP_RATE & GDP_PC & Adj R-sq (GDP) \\
\hline Dependent Variables & 0.783 & -0.0014 & $-0.00087 * *$ & 0.721 \\
\hline Adj_ROA & 0.591 & $-0.074 * *$ & $0.0015 * * *$ & 0.613 \\
\hline Adj_ROE & Source: Authors' compilation result (2021) \\
\hline Fixed Effects: Bank Name and Year & $* \mathrm{p}<0.1 ; * * \mathrm{p}<0.05 ; * * * \mathrm{p}<0.01$ \\
\hline
\end{tabular}

The adjusted ROE of large banks was positively affected by GDP per capita at $0.0015^{* * *}$ with the adjusted $R 2$ at $63.1 \%$. Meanwhile, the adjusted ROA of large banks was negatively affected by GDP per capita at $-0.00087 * *$ with the adjusted $R 2$ of $72.1 \%$.

In large banks, mobile phone penetration rates had a negative effect on Adj_ROA and Adj_ROE.

Table 9: Macroeconomic and Market Effects

\begin{tabular}{|l|l|l|l|l|l|}
\hline Hypothesis & Status & All banks & Small banks & Large banks \\
\hline Independent Variable: Mobile apps & Nil & X & X & X \\
\hline GDP Per Capital \& ROA & Positive & O & O & O \\
\hline GDP Per Capital \& ROE & Positive & X & O & X \\
\hline Mobile Phone Penetration Rate \& ROE & O & O & X \\
\hline Mobile Phone Penetration Rate \& ROA & Positive & O & O \\
\hline
\end{tabular}

Source: Authors' compilation result (2021)

Thus, the regression model shows the overall effect of GDP per capita on ROE. GDP and ROE have a strong relationship. As the economy develops at a faster rate, more capital will be required, thereby creating more credit and liquidity in the market. This promotes the banking business and its penetration into the Vietnamese economy in terms of capital inflows into the stock market, thus bringing higher returns to the banking industry and the above returns. Equity will be greater. ROE is affected more than ROA because ROE that reflects financial leverage / debt / investment can be affected more by the external macroeconomic environment. In addition, mobile banking penetration has a positive impact on ROA and ROE of small banks. Based on the above results, it can be concluded that banks 'performance is affected by banks' ability to leverage new technologies to innovate - in this study, Mobile banking, expanding their mobile banking customer base and activating their use.

\section{DISCUSSION OF RESEARCH RESULTS}

First of all, the regression results rejected the null hypothesis that the adoption of mobile banking technology has not affected all the financial indicators of all 
banks, because there is a significant correlation between the implementation of mobile banking technology by banks and its effectiveness. The table below summarizes the results of the null hypothesis and the test hypothesis:

Table 9 : The Results of the Null Hypothesis and the Hypothesis

\begin{tabular}{|c|c|c|c|c|}
\hline Hypothesis & Status & $\begin{array}{l}\text { All } \\
\text { banks }\end{array}$ & $\begin{array}{l}\text { Small } \\
\text { Banks }\end{array}$ & $\begin{array}{l}\text { Large } \\
\text { Banks }\end{array}$ \\
\hline \multicolumn{5}{|l|}{ Independent Variables: Mobile apps } \\
\hline $\begin{array}{l}\text { H0: Adoption of mobile technologies has no impact on all financial indicators } \\
\text { across all banks }\end{array}$ & Rejected & $\mathrm{X}$ & $\mathrm{X}$ & $\bar{X}$ \\
\hline $\begin{array}{l}\text { H1: Adoption will have a bigger impact on small banks than on large banks in terms } \\
\text { of fee income }\end{array}$ & Accepted & $\mathrm{O}$ & $\mathrm{O}$ & $\mathrm{X}$ \\
\hline $\begin{array}{l}\text { H2: Adoption will have a bigger impact on small banks than on large banks in terms } \\
\text { of operating income }\end{array}$ & Accepted & $\mathrm{O}$ & $\mathrm{X}$ & $\mathrm{O}$ \\
\hline $\begin{array}{l}\text { H3: Adoption will have a bigger impact on small banks's customer loans than on } \\
\text { large banks }\end{array}$ & Accepted & $\mathrm{O}$ & $\mathrm{O}$ & $\mathrm{O}$ \\
\hline H3: Adoption will have a bigger impact on small banks's ROA than on large banks & Accepted & $\mathrm{O}$ & $\mathrm{O}$ & $\mathrm{O}$ \\
\hline H4: Adoption will have a bigger impact on small banks's ROE than on large banks & Accepted & $\mathrm{X}$ & $\mathrm{O}$ & $\mathrm{X}$ \\
\hline
\end{tabular}
Source: Results of data processing by research team (2021)

Secondly, the impact of mobile banking technology on balance sheet liabilities has a positive impact on money market deposits, while in large and small banks, mobile banking applications have a negative impact on demand deposits and time deposits. These results are consistent with previous research by DeYoung (2007) in which new technology allows funds to be easily converted from spot, low deposit or perpetual deposits to high-yield money market funds. The performance of banks (measured as the ratio of money market deposits to total deposits) is very important because they get the most financial gains from e-commerce commission income. Jean (2017) discovered and summarized the impact of mobile banking applications on financial performance. The research is consistent with Karjaluoto (2002), who believes that in addition to the platforms provided by the banking system (such as checkbooks, ATMs, voicemail/line interfaces, smart cards, POS, and Internet resources), mobile phone platforms are another convenient method. Money management without cash processing. Therefore, the regression model shows that mobile banking technology is statistically significant in terms of fee income, which provides clear evidence to reject the null hypothesis and the alternative hypothesis are accepted. Compared with bank fees income, the adoption of mobile banking technology will have a greater impact on smaller banks.

"Thirdly, regression analysis also shows that there is a statistically significant correlation between wireless technology and the reduction of operating costs (such as general sales and management costs (SG\&A)). Therefore, the second assumption is that the introduction of mobile banking will have a greater impact on small banks than on large banks. These results are in line with previous research by Kiyono.H (2019). When customers need it, mobile technology can help banks provide services with minimal human involvement. Fast processing enables employees to provide services to customers through offline channels and continuously improve products and processes, thereby helping to reduce management costs. When banks apply it to the Vietnamese banking market, they are competing for digital banking, which is one of the key technologies that financial institutions and banks are paying attention to. Action points and customers can be covered by apps such as smartphones and social networks. The introduction of digital banking has brought many opportunities for banks. For example, these include, for example, increasing income, improving labor productivity and reducing costs, increasing access to information and data, connecting, collaborating, increasing competitiveness, and creating competition with competitors". 
Fourthly, the clear evidence is that there is a statistically significant relationship between adoption of mobile banking apps and transactional consumer loans among small businesses that provide one-off lending businesses. This includes mortgages, auto loans and credit cards that consumers can apply for through mobile devices. Banking applications provided by some commercial banks in Vietnam. Relationship loans are usually related to commercial loans. In this case, the bank monitors the performance of the borrower under the loan agreement over a period of time or provides other services (such as deposit accounts) to obtain information about the borrower in the relationship ((Allen, Saunders and Udell 1991; Petersen and Rajan 1994)). Therefore, the regression model shows that financial technology innovation is statistically significant to consumer loans, which supports the third hypothesis: Adoption will have a bigger impact on small banks's customer loans than on large banks. Banks that are smaller than the large e-commerce banks and their respective credit lines are generally smaller and based more on transactions than on loan/deposit transaction relationships that have generated profits over the years. Based on the transaction lending theories, it can be understood that mobile banking technology has had an impact on consumer loans.

"Finally, in terms of measuring the impact of mobile banking technology on the profitability of banks, the regression comes from the impact of mobile banking technology on the return on investment and return on equity of small banks. This supports the rejection of the original hypothesis and the acceptance of the fourth and fifth alternative hypotheses. The impact of small banks is much greater than the ROE and ROE of large banks. Other innovative theories that ICT plays a key role in reducing operating costs while generating new revenue streams also reflect the impact of product and process innovation brought about by mobile technology. This finding is consistent with the study of Kiyono (2019).
However, this conclusion is contrary to the results of Bashir (1999). Research shows that there is a relationship between profitability and bank size. The bigger the bank, the higher the profit margin. This shows that ROA and ROE have a greater impact on large banks. The reasons for the discrepancies between our research and the previous analysis. The researchers are partly due to the fact that the national background and the research time period are inconsistent".

\section{CONCLUSION}

To our knowledge, this research is one of the very few, if not the first, research conducted in Vietnam to investigate the impact of Fintech innovations on bank performance across mobile banking applications. The study results have broad implications for research. To begin with, the current research on the impact of fintech innovations on bank performance in Vietnam are mostly qualitative studies. Compared to us, our quantitative research investigates the impact of FinTech on banks financial performance carefully and in a comprehensive way through variables which come from all aspects in a bank's financial statements. Moreover, some previous research has shown that the impact of FinTech innovations on ROE was slightly. However, in Vietnam it can be seen from our regression results that $\mathrm{ROE}$ of banks is affected considerably by the development of FinTech. Last but not least, our studies have enriched the Strumpeter's Technological Innovation Theories especially on the first type of innovations: the introduction of a new product. In terms of future research, firstly, the studies may be ten years longer than ours, expanding the scope of the study to identify its effects over time. Secondly, it is very useful to expand the research field, when the impact of financial technology is no longer limited to the banking sector but is widely used across different industries.

Our studies have some practical implications. Firstly, the results show that FinTech innovations have a positive impact 
on bank performance in Vietnam. Subsequently, bank's adoption of mobile technologies positively impacted banks' feebased income, consumer loans and money market deposits. It is suggested that commercial banks in Vietnam should invest more about FinTech technologies to enhance their performance. Secondly, the effect of FinTech innovations laid a stronger impact on small banks than large banks. Large banks in Vietnam should consider further investment for a better financial system in the foreseeable future. Thirdly, the impact of market effects on a bank's financial performance is proved including GDP per capita, mobile phone penetration rate. Some recommendations have been suggested by our research team for both commercial banks and policy makers can be namely as further investment or legal framework for future.

\section{ACKNOWLEDGEMENT}

This paper is performed within the Ministerial Scientific Research Project "A Study on Conditions for Developing Fintech Ecosystem to Promote Finncial Inclusion in Vietnam/Nghiên cứu điều kiện phát triển hệ sinh thái Fintech thúc đẩy tài chính toàn diện ở Việt Nam”, Code B2021.KHA.04.

\section{Conflict of Interest: None}

\section{Source of Funding: None}

\section{REFERENCES}

1. Abbasi, T., \& Weigand, H.,.The Impact of Digital Financial Services on Firm's Performance: a Literature Review, Tilburg School of Economics and Management, Tilburg University, the Netherlands, 2017.

2. Aburime, U.,. Determinants of Bank Profitability: Company-Level Evidence from Nigeria. Nigeria: University of Nigeria, Enugu Campus,2005.

3. Al-Tamimi, H., Hassan, A.,. Factors Influencing Performance of the UAE Islamic and Conventional National Banks. Department of Accounting, Finance and Economics, College of Business Administration, University of Sharjah,2018.
4. Athanasoglou,P.P.,Brissimis,S.N.\& Delis,M.,.'Bank-specific, industry-specific and macroeconomic determinants of bank profitability', Journal of International Financial Markets, Institutions and Money, Vol. 18, No. 2,2008, pp.121-136

5. Bank of New York Mellon., Innovation in Payments: The Future is FinTech, 2016.

6. Baron, R. M., \& Kenny, D. A.,.The moderator-mediator variable distinction in social psychological research: Conceptual, strategic and statistical considerations. Journal of Personality and Social Psychology, 51,1986, 1173- 1182.

7. Berger. A. N., Nathan H. M., Mitchell. A. P., Raghuram. G. R., \& Jeremy C. S.,. "Does Function Follow Organizational Form? Evidence from the Lending Practices of Large and Small Banks," Journal of Financial Economics, Elsevier, vol. 76, no. 2,2005, pp. 237-269.

8. Berraies, S. B. Y. K. \&. H. M.,. Identifying the effects of perceived values of mobile banking applications on customers: Comparative study between baby boomers, generation $\mathrm{X}$ and generation $\mathrm{Y}$. International Journal of Bank Marketing, 35(6),2017, pp. 1018-1038.

9. Chen, M., Wu, Q., and Yang, B.,. 'How valuable is FinTech innovation?', The Review of Financial Studies,2019, 32 (5): 2062-2106.

10. Cam Nhung \& Mai Phuong.,. Fintech và xu hướng hợp tác với hệ thống ngân hàng thương mại tại Việt Nam,2021.

11. Del Giudice, Manlio ; Campanella, Francesco ; Dezi, Luca.,. The bank of things: An empirical investigation on the profitability of the financial services of the future, Emerald Group Publishing Limited,2016, ISSN 1463-7154, ZDB-ID 1379961-7. - Vol. 22.

12. DeYoung, R., \& Hunter, W. C.Deregulation.,. The Internet and the competitive viability of large banks and community banks, The Future of Banking, Benton Gup Greenwood Press Quorum Books,2001.

13. DeYoung, R., \& Rice, T.,. Noninterest income and financial performance at US commercial banks. Financial Review, 2004,39(1), 101-127. 157.

14. DeYoung, R., \& Rice, T.,.How do banks make money? The fallacies of fee income. 
Economic Perspectives-Federal Reserve Bank of Chicago, 2003,28(4), 34.

15. DeYoung, R., Lang, W., and Nolle, D.,.How the Internet affects output and performance at community banks, Journal of Banking \& Finance 31, 2007, pp. 1033-1060.

16. Financial Stability Board, "FinTech and market structure in financial services: Market developments and potential financial stability implications", February,2019

17. Flamini, V., McDonald, C. and Schumacher, L.,. 'The determinants of commercial bank profitability in SubSaharan Africa', International Monetary Fund Working papers, 2009.

18. Fries, S., and Taci, A.,.Cost Efficiency Of Banks In Transition Evidence From 289 Banks In 15 Post Communist Countries, Journal of Banking and Finance,2005 pp. 55-81.

19. Gomber, P., Koch, J. A., and Siering, M.,."Digital Finance and FinTech: current research and future research directions", Journal of Business Economics, Vol. 87, No. 5,2017, pp. 537-580.

20. Gemechu B. Kusa, Vincent O. Ongore.,.Determinants of Financial Performance of Commercial Banks in Kenya, International journal of economics and financial issuesVol. 3, No. 1, 2013, pp.237-252

21. Guru, B., Staunton, J. and Balashanmugam, B.,.Determinants of commercial bank profitability in Malaysia, University Multimedia Working paper,2002.

22. Hai T. Phan, Tien N. Hoang, Linh V. Dinh , Dat N. Hoang.,2020. The Determinants of Listed Commercial Banks' Profitability in Vietnam, Hai T. Phan, Tien N. Hoang, Linh V. Dinh , Dat N. Hoang.,. The Determinants of Listed Commercial Banks' Profitability in Vietnam,Vo.7 No.11,2020, p.219-229

23. Hauwa D. Bagudu, Shazida J.M Khan, Roslan A. Hakim.,.The Effect of Mobile Banking on the Performance of Commercial Banks in Nigeria. International Research Journal of Management, IT \& Social Sciences, 2017,Vol. 4 No. 2, p.74-80.

24. Harrison Stewart., Jan Jürjens.,.Data security and consumer trust in FinTech innovation in Germany, Information \& computer security, 2018,No.1, pp.109128.ISSN: 2056-4961
25. Henderson, R,. \& Clark, K.,. Architectural Innovation: The Reconfiguration of Existing Product Technologies and the Failure of Established Firms. Administrative Science Quarterly,1990, Vol. 35, No. 1, Special Issue: Technology, Organizations, and Innovation, pp. 9-30

26. Hornuf, L., Klus, M. F., Lohwasser, T. S., \& Schwienbacher, A.,. How Do Banks Interact with FinTechs? Forms of Alliances and their impact on Bank Value, 2018No. 7170.

27. Hong Thanh., Số hóa hoạt động ngân hàng Cần một tư duy phát triển mới,2020

28. Hai Nam.,. Sandbox cho Fintech: Cần một bước đi thận trọng, 2020.

29. Lee, K. \& Chung, N.,. Understanding factors affecting trust in and satisfaction with mobile banking in Korea: A modified DeLone and McLean's model perspective. Interacting with computers, 2009,21(5/6), pp. 385-392.

30. Lee, S., 2015. FinTech and Korea's financial investment industry.

31. Ilyas Akhisar, K. Batu Tunay, Necla Tunay.,. The Effects of Innovations on Bank Performance: The Case of Electronic Banking Services. Procedia - Social and Behavioral Sciences, 2015,Vol. 195, pp. 369-375.

32. Li, Y.,2007. Determinants of Banks. Profitability and its Implication on Risk Management Practices: Panel Evidence from the UK in the Period 1999-2006.

33. Japparova, I. \& Rupeika-Apoga, R.,.Banking Business Models of the Digital Future: The Case of Latvia, European Research Studies Journal, Volume XX, Issue 3A, 2017, pp.846-860.

34. Kiesnoski, K.,. Wireless Banking. Bank Systems \& Technology, 2020,7(2), pp. 4043

35. Khanh N.Nguyen., Revenue Diversification, Risk and Bank Performance of Vietnamese Commercial Banks, Journal of Risk and Financial Management, 2019,12(3),138.

36. KPMG., FinTech in India A global growth story, 2016.

37. Kuo Chuen, D. L., \& Teo, E. G.,. Emergence of FinTech and the LASIC principles. Journal of Financial Perspectives, 2015,3(3), 24-36.

38. Kim Chi.,. Quản lý công ty công nghệ tài chính ở các nước và triển vọng phát triển tại Việt Nam,2021. 
39. Mongid, A.,. Business efficiency of the commercial banks in ASEAN. Investment Management and Financial Innovations, 2016, 13(1), 67-76.

40. Mongid, A., Tahir, I. M., \& Haron, S., The determinants of bank cost inefficiency in ASEAN Banking. Jurnal Pengurusan,2012., 36, 69-76.

41. Minh Phuong., Ngân hàng số giúp giảm chi phí giao dịch và gia tăng lợi nhuận,2021

42. Ngoc Thuy, Great potential to promote development of digital banking in Vietnam: Brokerage, 2019.

43. Nguyen V., Phát triển, FinTech: Chất hay lượng? Thời Báo Ngân Hàng,2020.

44. Pegueros, V.,.Security of Mobile Banking and Payments. SANS Institute Information Security Reading Room, 2012.

45. Prateek Saxena, 2020. What Type of Mobile Apps Will Tech Investors Fund in 2020.

46. Priya, R., Gandhi, A. V. \& Shaikh, A., Mobile banking adoption in an emerging economy: An empirical analysis of young Indian consumers. Benchmarking: An International Journal,2018, 25(2), pp. 743762.

47. Phan Linh, Úng dụng công nghệ tài chính trong chuyển đổi số của ngân hàng hiện nay., 2019.

48. Rega, F.,. The bank of the future, the future of banking - An empirical analysis of European banks, Department of Economics, Second University of Naples, 2017.

49. Regehr, K., \& Sengupta, R.,. Has the relationship between bank size and profitability changed?, Economic Review (01612387), 2016,p.101.

50. Schumpeter, J., The Theory of Economic Development, Cambridge Mass, Harvard University Press, 1934.

51. Son T.Nghiem.,FinTech tại Vietnam: Nắm bắt $\mathrm{xu}$ hướng để "chuyển mình" phát triển, 2019.

52. Shen, Z., Liao, H. and Weyman-Jones, T.,.Cost Efficiency Analysis in Banking Industries of Ten Asian Countries and Regions, Journal of Chinese Economics and Business Studies, 2009,7 (2), pp. 199-218.

53. Tin H.Ho.,.Financial Performance and Income Diversity: Does Ownership Matter? Evidence from Vietnamese Commercial Banks, International Journal of Economics and Finance Archives,2020, Vol. 12, No.8.

54. Trang, ĐH.,Vietinbank - Ngân hàng điện tử tiêu biểu nhất Vietnam, 2018.

55. Tunay, K. B., Tunay, N., \& Akhisar, İ.,. Interaction between Internet banking and bank performance: The case of Europe. Procedia-Social and Behavioral Sciences, 2015,195, 363-368.

56. VCB News, Thanh toán di động - Xu hướng thanh toán hiện đại nhiều tiện ích.,2019.

How to cite this article: Tam T. Le, Ha N. Mai, Duong T. Phan et.al. Fintech innovations: the impact of mobile banking apps on bank performance in Vietnam. International Journal of Research and Review. 2021; 8(4): 391-401. DOI: https://doi.org/10.52403/ijrr.20210446 